\title{
Sedimentation processes and beach morphodynamics active at the Doce River mouth, Espírito Santo State, Brazil
}

\author{
JACQUELINE ALBINO $^{1}$ and KENITIRO SUGUIO ${ }^{2}$ \\ ${ }^{1}$ Departamento de Oceanografia e Ecologia, Universidade Federal do Espírito Santo (UFES) \\ Av. Fernando Ferrari, 514, 29075-915 Vitória, ES, Brasil \\ ${ }^{2}$ CEPPE - Centro de Pós-graduação, Pesquisa e Extensão, Universidade Guarulhos (UnG) \\ Praça Tereza Cristina, 1, Centro, 07023-070 Guarulhos, SP, Brasil \\ Manuscript received on November 4, 2008; accepted for publication on August 25, 2010
}

\begin{abstract}
The coastal sedimentation model in the Doce River mouth and surroundings extends beyond the hydraulic jetty effect created by its stream-flow. During flooding, marine sediments transported by longshore currents are retained on the updrift side, causing strandline progradation. As the longshore current direction varies, local depositional and erosional effects can be produced and identified laterally within beach profiles from north and south of the Doce River mouth area. Sedimentological studies carried out in this river, beach and adjacent inner continental shelf sands showed that, at present, the influence of Doce River sediments is restricted to the area surrounding its mouth. Meanwhile, beach morphodynamic stages and present-day coastal-plain processes of sedimentation are directly affected by the Doce River discharge as a natural continuation of the Quaternary geological evolution of the area.
\end{abstract}

Key words: coastal processes, beach morphodynamics, Quaternary evolution, Doce River, Brazil.

\section{INTRODUCTION}

The Quaternary geological evolution of the Doce River delta plain, Espírito Santo State (Brazil), was studied by Martin and Suguio (1992). According to these authors, during the Middle Holocene, almost all the sediments supplied by the Doce River were retained within a large lagoon located behind a barrier island. This system of deposition was formed during the Holocene relative sea-level culmination stage, about 5.5ky BP. However, about $2.5 \mathrm{ky}$ BP, the coastal lagoon became completely filled and the river began to unload its sediments and waters directly into the Atlantic Ocean. Several longshore current inversions (northward and southward) occurred during the Holocene. Unstable heavy minerals, identified by Coutinho (1974) in present-day beaches of this area, suggest that they were supplied by the Doce River.

Correspondence to: Jacqueline Albino

E-mail: jacqueline.albino@terra.com.br
When trade winds are dominant, longshore currents flow from north to south. By contrast, during cold front incursions, the dominant winds blow from the southeast or southwest, and the longshore currents flow from south to north. Trade winds are more frequent in the study area. However, during "El Niño" climatic anomalies, the polar advections are blocked southward by the jet stream. Consequently, during these times, they do not reach the study area, and longshore currents that flow from north to south due to the effect of the trade winds become more effective in the transportation and distribution of sediments.

Dominguez et al. (1983), among others, emphasized the hydraulic jetty effect of the Doce River as an important control in its coastal sedimentation model. During episodes of river flooding, most of the marine sediment transported by longshore currents is deposited on the updrift side, which entails beach profile deposition. Conversely, with changes in the direction of long- 
shore currents, beach profile erosion is observed. According to Martin and Suguio (1992), this kind of phenomenon occurred repeatedly in this area, and would be responsible for the asymmetry of this coastal plain.

The aim of this study is to constrain the role of Doce River sediments and the rivers hydraulic jetty effect on influencing the adjacent beach morphodynamics. This comparison will lead to a better understanding of the hydrodynamic processes that have occurred along river mouths in the late Quaternary.

\section{STUDY AREA}

The study area $\left(19^{\circ} 30^{\prime}-19^{\circ} 50^{\prime} \mathrm{S}, 39^{\circ} 35^{\prime}-40^{\circ} 05^{\prime} \mathrm{W}\right)$ comprises the delta plain of the Doce River and the adjacent continental shelf up to $16 \mathrm{kms}$ from the coast (Fig. 1).

The following four geomorphological units, from west to east, can be recognized in the area: (1) a mountainous area, which is composed of deeply-weathered Precambrian crystalline rocks, with encased valleys and a multidirectional rectangular dendritic drainage net; (2) a tableland area composed of the Barreiras Formation continental deposits (Neogene), with subparallel valleys, and a drainage net that follows a gentle slope seaward; (3) a coastal plain area, with fluvial, transitional and shallow marine sediments, which were deposited during changes in sea-level in the Quaternary (Martin and Suguio 1992) and (4) an inner continental shelf area, about $50 \mathrm{~km}$ wide at the Doce River mouth area, but enlarging northward as a consequence of Cenozoic volcanic activities that gave rise to the construction of the Abrolhos Bank (Asmus et al. 1971). According to França (1979), the continental shelf surface is smooth to a depth of $20 \mathrm{~m}$ due to the silting up of abundant fluvial sediments.

This coast is characterized by summer and spring tropical rainfall, with periods of drought in autumn and winter. However, rain may also fall in autumn and winter, due to periodic cold front incursions. The most frequent and intense winds are northeasterly/east-northeasterly and southeasterly. The northeasterly winds blow almost all year round, and are related to the trade winds. The southeasterly winds are related to polar advections, and reach the area periodically. According to Melo and Gonzalez (1995), the most effective and important waves come from the east-northeast or south- southeast and can be associated with the above-mentioned wind patterns.

\section{MATERIALS AND METHODS}

Beach transverse profiles were taken between January 1996 and January 1997 at six stations: P1-P6 (Fig. 1).

An auto level and a laser range finder were used to survey the beach profiles, which were extended from a fixed point at the reverse of the frontal dune to the plunge step or furthermore, to a point allowed by the wave condition. The vertical datum adopted was the mean tidal level $(0.82 \mathrm{~m}$ - Diretoria de Hidrografia e Navegação, DHN) meaning the vertical zero on the plotting.

These morphological surveys were accompanied by visual estimations of breaking waves according to the proposal put forward by Komar (1976). These data were analyzed together with synoptical charts of 1998 from Instituto Nacional de Pequisas Espaciais (INPE) and the information about tidal levels for 1996 and 1997 from the DHN. Longitudinally transported directions and volume of sands $\left(\mathrm{m}^{3} /\right.$ day) were calculated using the following equations from Komar (1976):

$$
Q s=3.4(E C)_{b} \operatorname{sen} \alpha \cos \alpha
$$

where $C$ corresponds to the wave celerity, which is determined by the equation

$$
C=\sqrt{g}\left(2 H_{b}\right)
$$

and $E$ represents wave energy, which is calculated by

$$
E=1 / 8\left(\rho g H_{b}^{2}\right)
$$

with $\rho$ as the seawater density $\left(1032 \mathrm{~kg} / \mathrm{m}^{3}\right), \mathrm{g}$ is the gravity acceleration $(9,8 \mathrm{~m} / \mathrm{s})$ and $\alpha$ is the angle of incidence between wave crest and strandline.

Sedimentological studies consisted of grain size analysis using the Wentworth's (1922) scale, whose statistical treatments followed the proposals of Folk and Ward (1957); morphometrical analysis was done according to Pettijohn (1957); and facies definitions followed the schemes presented in Larsonneur (1977). The samples were collected: a) on the berm of the six profiles along present-day beaches during the 12 months, b) from Doce River ( $\left.19^{\circ} 50^{\prime} 53^{\prime \prime} \mathrm{S}, 39^{\circ} 53^{\prime} 25^{\prime \prime} \mathrm{W}\right)$, Comboios 


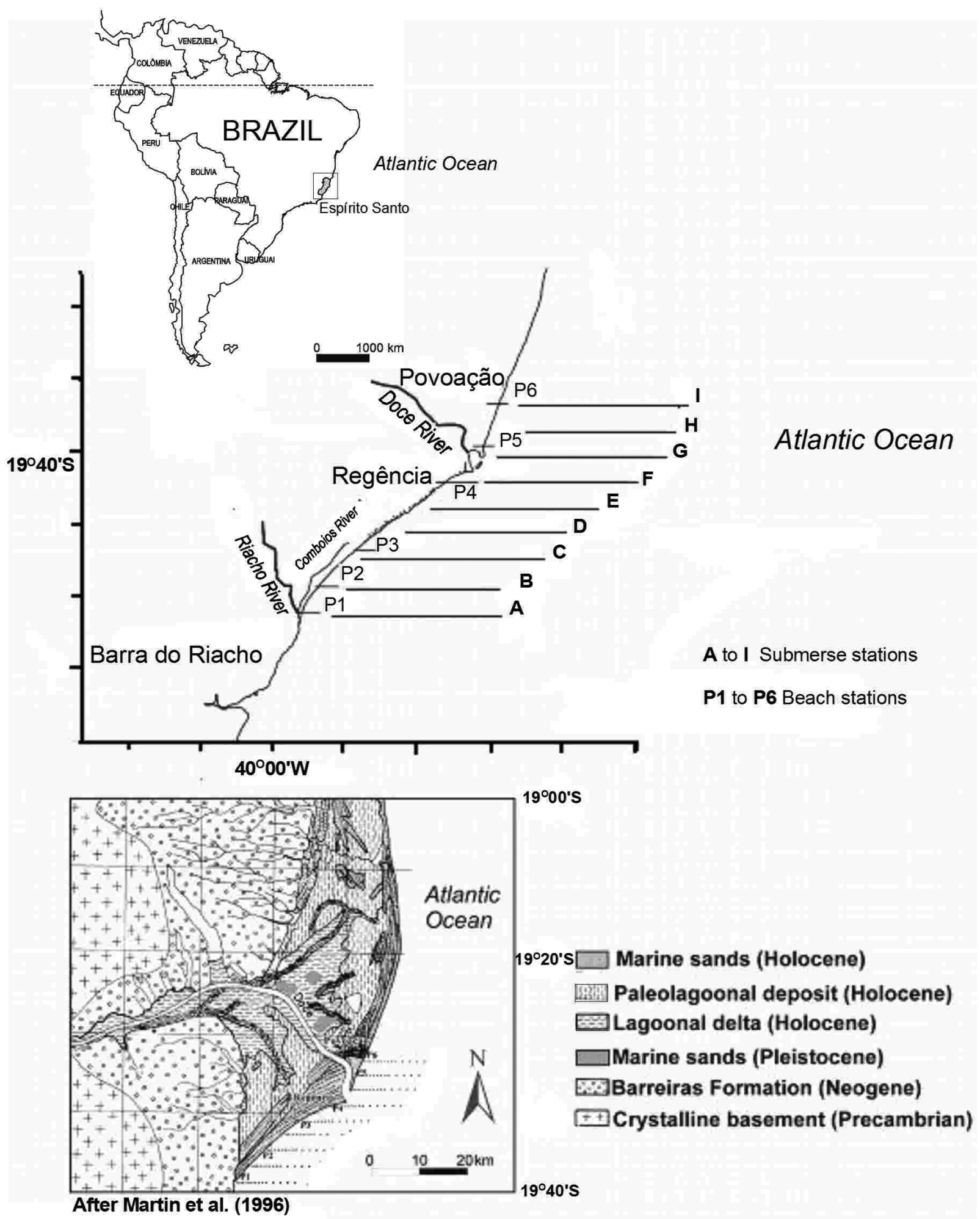

Fig. 1 - Location map of the study area, Doce River delta plain, Espírito Santo State, Brazil. 
River $\left(19^{\circ} 46^{\prime} 41^{\prime \prime} \mathrm{S}, 40^{\circ} 02^{\prime} 30^{\prime \prime} \mathrm{W}\right)$ and Riacho River, ( $19^{\circ} 47^{\prime} 43^{\prime \prime} \mathrm{S}, 40^{\circ} 03^{\prime} 18^{\prime \prime} \mathrm{W}$, datum Córrego Alegre), and c) on the adjacent inner continental shelf bottom surface, along 9 transversal profiles with 11 stations each in December 1996 (Fig. 1).

\section{RESULTS AND DISCUSSION}

\section{Sedimentological Studies of Fluvial Sediments}

The sands discharged by the Riacho River into the Atlantic Ocean are composed of a mixture of sediments from the Neogene Barreiras Formation, and are transported by Doce River sediments that originated in mountainous areas and Tertiary tablelands. They are composed mainly of moderately sorted coarse to very coarse sands (Fig. 2).

The sediments from the Doce River bottom are composed of marginal coarse sands, with modal fractions situated between 1 and 0 phi, and central fine sands, dominated by fractions between 2.5 and 2 phi. Mud is absent from the bottom load. However, the water turbidity suggested that mud is not negligible within the suspension load.

The inner continental shelf bottom surface sediments, next to the Doce River mouth, are dominated by sandy and muddy sand siliciclastic sediments supplied by this river (Fig. 3). The offshore dispersion of the Doce River fluvial sediments occurs up to about $15 \mathrm{~km}$ from the coast. The fluvial sediments are gradually replaced by biosiliciclastic sands, which are probably dominant at the bottom surface of the outer continental shelf. Between Comboios beach and the Riacho River mouth, the submerged portion is filled predominantly by medium to coarse siliciclastic sands. Bioclastic and mixed sands have been observed only at the bottom surface of the southern continental shelf.

\section{Sedimentological Studies of BeACH SANDS}

The beach sands of Barra do Riacho (P1) showed slight variations in grain size during the sampling period. They are characterized by moderately-sorted very coarse sands, whose modal fraction lies between -1 and 0 phi (Fig. 4). On the Comboios (P2) beach, the sands are well sorted. Coarse to very coarse sands have only been observed in April, but other samplings have indicated moderately-sorted coarse sands.

The sediments from Comboios (P3) and Regência (P4) beaches exhibited moderately-sorted and medium to coarse sands. The seaward extension of P3, 10 to $25 \mathrm{~m}$ away from the maximum wave retreat, presented fine sands in January 1996. However, a tendency towards coarsening occurred from August to October 1996. The sediments from Povoação (P5 and P6) beach were moderately to well sorted, coarse to very coarse sands. In general, sands exhibited a tendency towards coarsening and better sorting during or after cold front incursions.

At the sampling stations situated southward of the Doce River mouth (P1 to P4) it was observed a direct relationship between a coarsening in mean diameter and an increase in degrees of roundness (Fig. 5). The very coarse sands of Barra do Riacho became medium to coarse toward the Riacho River mouth, with a simultaneous decrease of the degrees of roundness. By contrast, at Povoação beach situated northward of the Doce River mouth, samples taken next to the mouth (P5) exhibited less reworked siliciclastic grains. Northward, at Station P6, the sands became coarser and had the highest degrees of roundness. Less roundness in siliciclastic grains from beaches to the Doce River mouth suggests that they are supplied directly by this river.

Sedimentological characteristics of beach and inner continental shelf bottom surface sediments indicate that the influence of the Doce River is restricted to the neighbourhood of its mouth. To the south, the grain size resemblance between (a) the Riacho and Comboios Rivers crossing the delta plain, (b) Barra do Riacho beach, and (c) the adjacent continental shelf, suggests that there is an active interplay among these different environments.

\section{Meteorological And OCEANOGRaphic Conditions}

The meteorological conditions and the lunar phases obtained during the sampling period are summarized in Table I. During 1996, the surface temperature of the Atlantic Ocean in the region adjacent to the study area exceeded the climatological average, due to a semi-constant state of cold fronts in SE Brazil (INPE 1998). This situation was responsible for high pluviosity during that year in SE states, and rain fell on most of the sampling days of the study. 

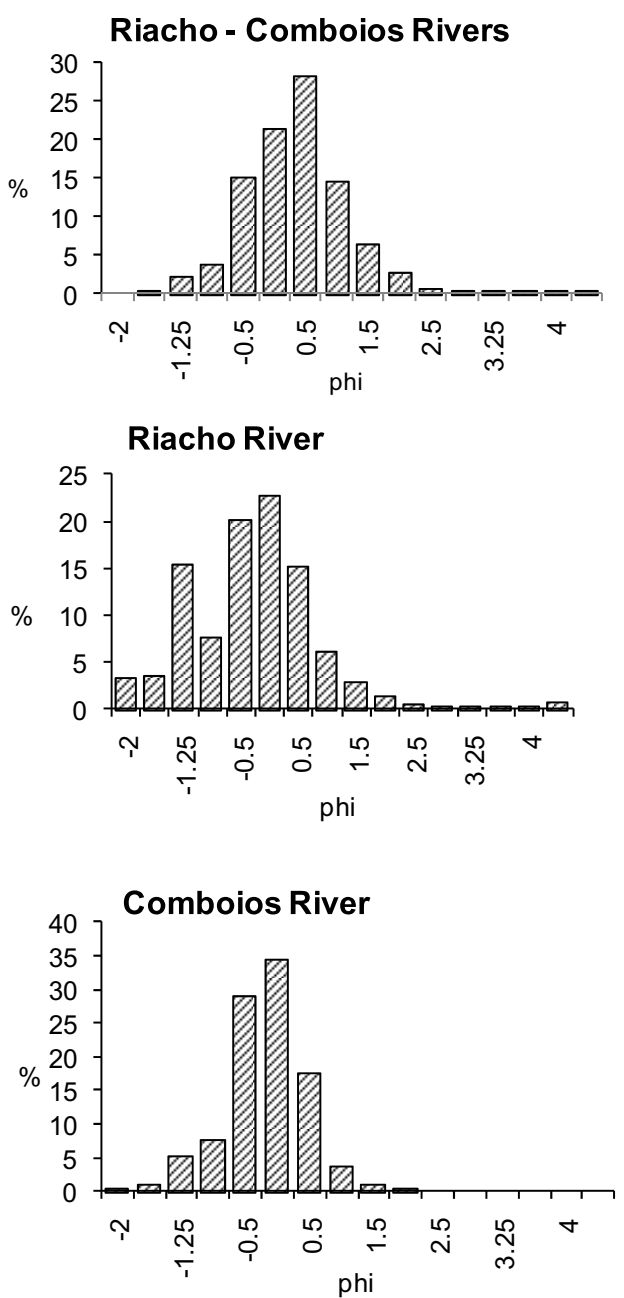
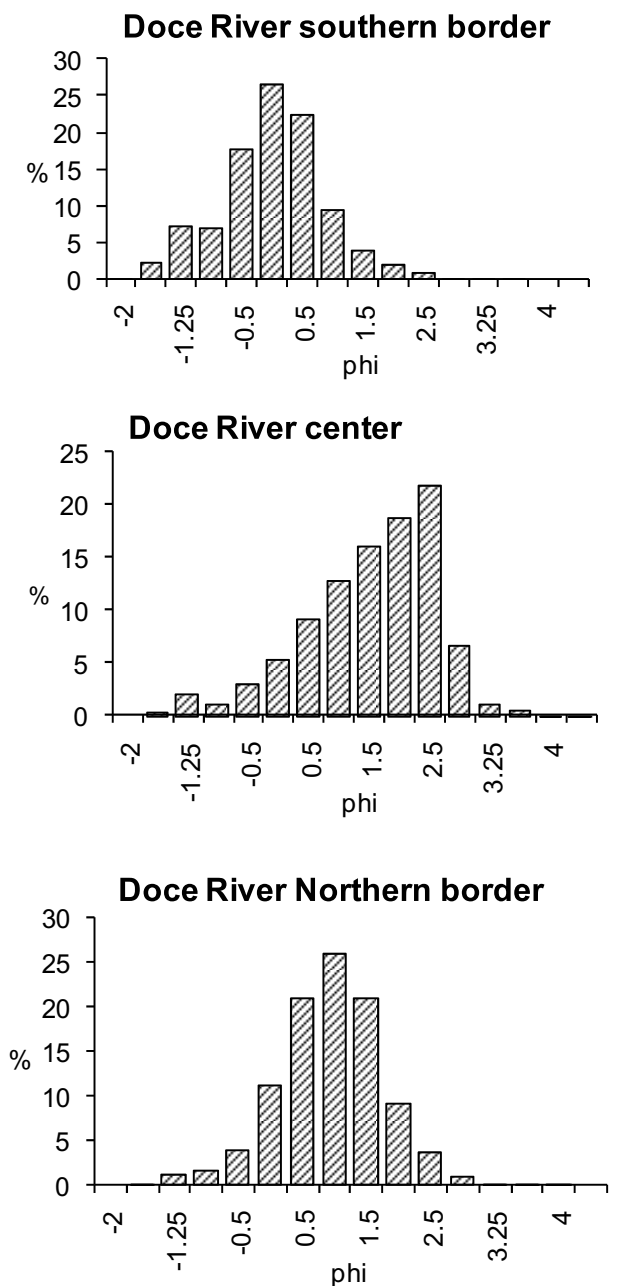

Fig. 2 - Grain size distribution of Comboios and Doce River samples. The sediments are composed mainly of moderately sorted coarse to medium sands. Mud is absent from the bottom load.
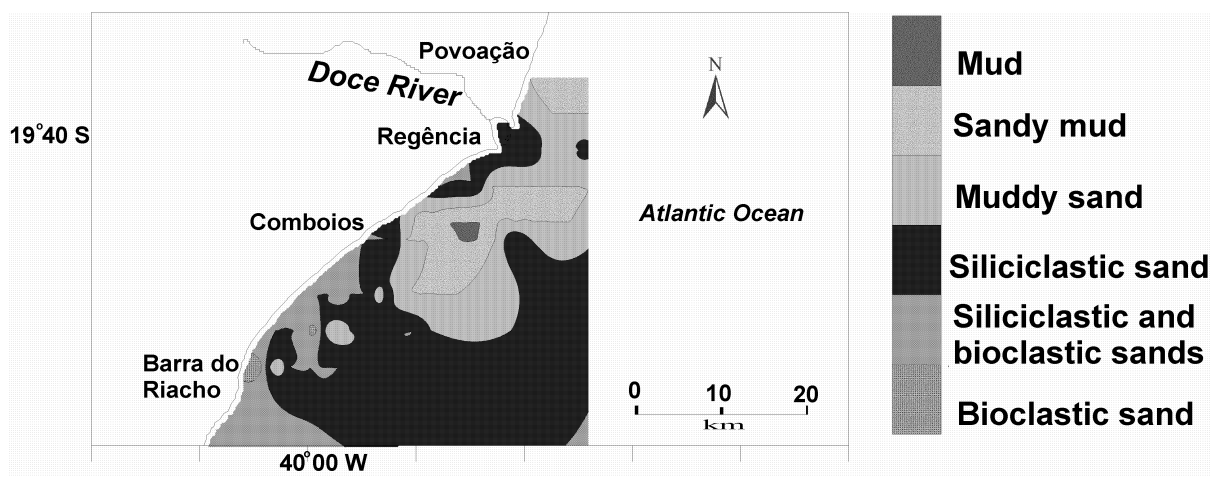

Fig. 3 - Faciology of inner continental shelf bottom surface sediments between Barra do Riacho and Povoação beaches. The sediments are composed of siliciclastics mud and sands supplied by the recent input from the Doce River. 
Barra do Riacho beach P1

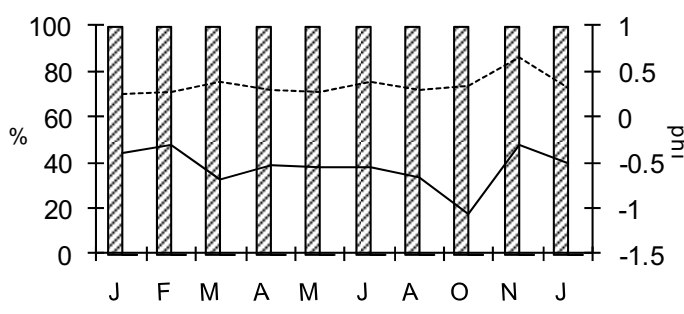

Comboios beach P3

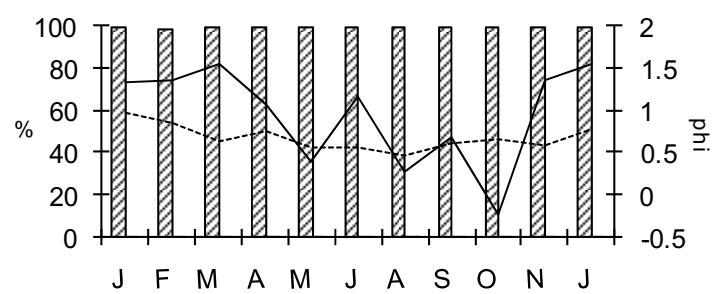

Povoação beach P5

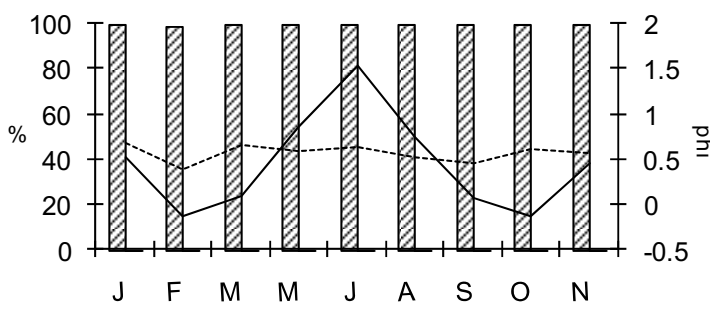

Comboios beach P2

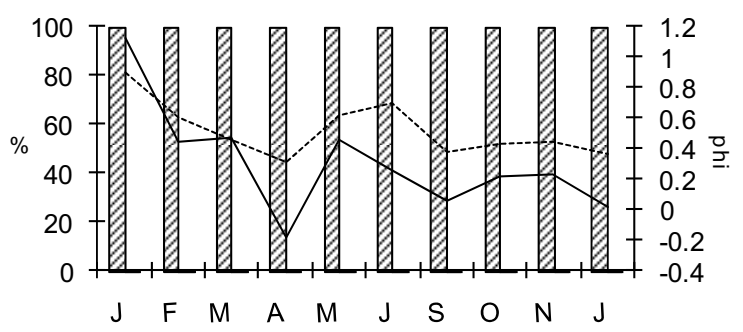

Regência beach P4

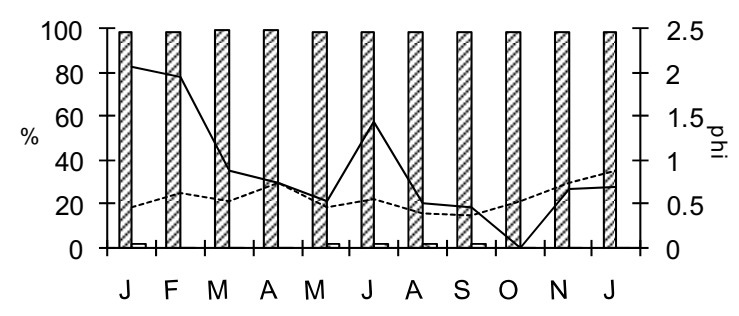

Povoação beach P6

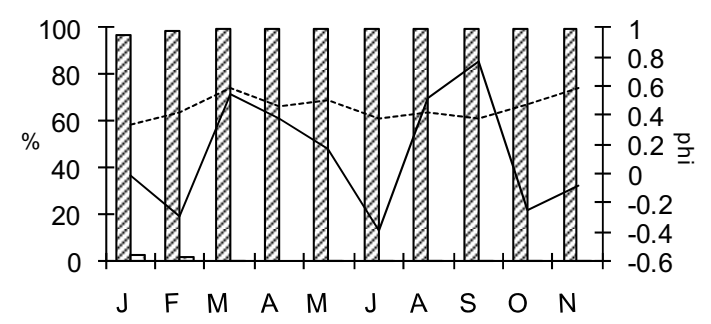

Fig. 4 - Composition, mean diameter $(\mathrm{Mz})$ and sorting of the sands of the beaches on the Doce River delta plain.

The siliciclastic sands are medium to coarse.

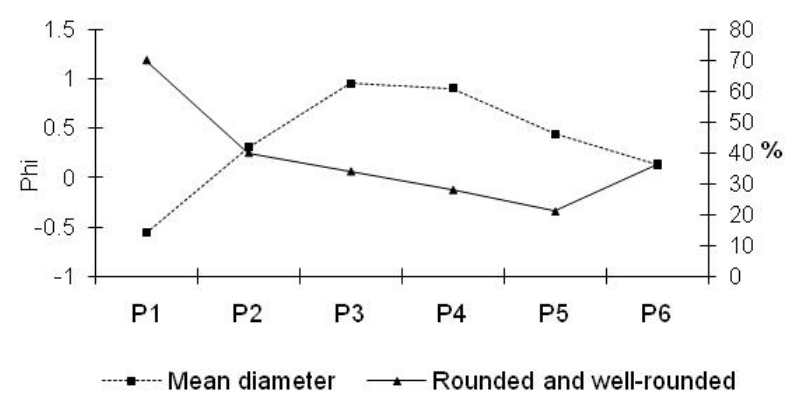

Fig. 5 - Mean diameter (Mz) and roundness percentage (\%) of the sands of the delta plain. The poor degrees of roundness of medium sands indicated fluvial input.

According to Aubrey (1983) and Wright and Short (1984), open-sea swells represent the most important energy input into beach environments and are also re- sponsible for their morphological variability, following transformations introduced in intermediate and shallow waters. Based on the resemblance between wave periods and heights, forecasts for the open sea, and synoptical charts for sampling days, it was possible to distinguish three different types of wave climate. These are shown in Table II.

Meteorological and lunar phase conditions were similar during the campaigns in January, February, March, July and September 1996 and January 1997. The wind speed ranged between 11 and 16 knots, which are moderate according to the Beaufort scale.

Dominated by the South Atlantic Tropical Anticyclone, winds came from the northeast, except for two days of the September campaign, when barometric 
TABLE I

Meteorological conditions and lunar phases during the sampling campaigns. Source INPE (1998).

\begin{tabular}{|c|c|c|c|c|}
\hline Days & Winds & $\begin{array}{l}\text { Waves } \\
\text { (height and period) }\end{array}$ & Observations & $\begin{array}{l}\text { Lunar } \\
\text { phases }\end{array}$ \\
\hline $\begin{array}{l}\text { January } 18^{\text {th }}, 19^{\text {th }} \\
\text { and } 20^{\text {th }} \text { of } 1996\end{array}$ & $\begin{array}{c}\text { NNW } \\
11-16 \text { knots }\end{array}$ & $\begin{array}{c}1.0-1.5 \mathrm{~m} \\
3-4 \mathrm{~s}\end{array}$ & Cloudy & Waning \\
\hline $\begin{array}{l}\text { February } 12^{\text {th }}, 13^{\text {th }} \\
\text { and } 14^{\text {th }} \text { of } 1996\end{array}$ & $\begin{array}{l}\text { NNE-NNW } \\
11-16 \text { knots }\end{array}$ & $\begin{array}{c}1.0-1.5 \mathrm{~m} \\
3-4 \mathrm{~s}\end{array}$ & Downpour & Waning \\
\hline $\begin{array}{l}\text { March } 15^{\text {th }}, 16^{\text {th }} \\
\text { and } 17^{\text {th }} \text { of } 1996\end{array}$ & $\begin{array}{c}\text { N-ENE } \\
28-33 \text { knots }\end{array}$ & $\begin{array}{c}1.0-1.5 \mathrm{~m} \\
3-4 \mathrm{~s}\end{array}$ & Downpour & Waning \\
\hline $\begin{array}{l}\text { April } 19^{\text {th }}, 20^{\text {th }} \\
\text { and } 21^{\text {st }} \text { of } 1996\end{array}$ & $\begin{array}{c}\text { SE } \\
28-33 \text { knots }\end{array}$ & $\begin{array}{c}2.3-3.0 \mathrm{~m} \\
6-7 \mathrm{~s}\end{array}$ & Intermittent rain & New \\
\hline $\begin{array}{l}\text { May } 17^{\text {th }}, 18^{\text {th }} \\
\text { and } 19^{\text {th }} \text { of } 1996\end{array}$ & $\begin{array}{c}\text { E-SE } \\
11-16 \text { knots }\end{array}$ & $\begin{array}{c}2.0-3.0 \mathrm{~m} \\
4-5 \mathrm{~s}\end{array}$ & Cloudy & New \\
\hline June $14^{\text {th }}$ of 1996 & $\begin{array}{c}\text { E-SE } \\
11-16 \text { knots }\end{array}$ & $\begin{array}{c}1.5-2.0 \mathrm{~m} \\
4 \mathrm{~s}\end{array}$ & $\begin{array}{c}\text { Cloudy and } \\
\text { moderate rain }\end{array}$ & Waning \\
\hline $\begin{array}{c}\text { July } 19^{\text {th }}, 20^{\text {th }} \\
\text { and } 21^{\text {st }} \text { of } 1996\end{array}$ & $\begin{array}{c}\text { N-NE } \\
11-16 \text { knots }\end{array}$ & $\begin{array}{c}1.0-1.5 \mathrm{~m} \\
3-4 \mathrm{~s}\end{array}$ & Semi cloudy & New \\
\hline $\begin{array}{l}\text { August } 16^{\text {th }}, 17^{\text {th }} \\
\text { and } 18^{\text {th }} \text { of } 1996\end{array}$ & $\begin{array}{c}\text { S-SE } \\
17-21 \text { knots }\end{array}$ & $\begin{array}{c}1.5-2.0 \mathrm{~m} \\
4 \mathrm{~s}\end{array}$ & $\begin{array}{l}\text { Cloudy and } \\
\text { downpour }\end{array}$ & New \\
\hline $\begin{array}{l}\text { September } 20^{\text {th }}, 21^{\text {st }} \\
\text { and } 22^{\text {nd }} \text { of } 1996\end{array}$ & $\begin{array}{c}\text { NE-SE } \\
11-16 \text { knots }\end{array}$ & $\begin{array}{c}1.0-1.5 \mathrm{~m} \\
3-4 \mathrm{~s}\end{array}$ & $\begin{array}{c}\text { Semicloudy and } \\
\text { downpour }\end{array}$ & Crescent \\
\hline $\begin{array}{l}\text { October } 17^{\text {th }}, 19^{\text {th }} \\
\text { and } 20^{\text {th }} \text { of } 1996\end{array}$ & $\begin{array}{c}\text { ENE-SE } \\
11-16 \text { knots }\end{array}$ & $\begin{array}{c}1.5-2.0 \mathrm{~m} \\
4 \mathrm{~s}\end{array}$ & $\begin{array}{l}\text { Cloudy and } \\
\text { downpour }\end{array}$ & New \\
\hline $\begin{array}{c}\text { November } 15^{\text {th }}, 16^{\text {th }} \\
\text { and } 17^{\text {th }} \text { of } 1996\end{array}$ & $\begin{array}{c}\text { NNE } \\
17-21 \text { knots }\end{array}$ & $\begin{array}{c}2.0-2.5 \mathrm{~m} \\
4-5 \mathrm{~s}\end{array}$ & $\begin{array}{l}\text { Cloudy and } \\
\text { downpour }\end{array}$ & New \\
\hline $\begin{array}{l}\text { January } 21^{\text {st }}, 22^{\text {nd }} \\
\text { and } 23^{\text {rd }} \text { of } 1997\end{array}$ & $\begin{array}{c}\text { NNE } \\
11-16 \text { knots }\end{array}$ & $\begin{array}{c}1.0-1.5 \mathrm{~m} \\
3-4 \mathrm{~s}\end{array}$ & Cloudy & Crescent \\
\hline
\end{tabular}

pressure decrease and the wind changed direction, with a probable cold front incursion. Wave heights from 1 to $1.5 \mathrm{~m}$ and periods of 3 to $4 \mathrm{~s}$ had been forecast for the open sea. Concerning the lunar phases, the campaigns were carried out under waning or crescent moons except in July, which was carried out under a new moon.

In the June and August campaigns, as well as on 17th October 1996, the forecasted waves, 1.5 to $2 \mathrm{~m}$ high and with periods of $4 \mathrm{~s}$, were generated by cold fronts. The incursions came from south-southeasterly, developing winds of 11 to 21 knots. On $19^{\text {th }}$ and $20^{\text {th }}$ October, and on $16^{\text {th }}$ and $17^{\text {th }}$ November 1996 , north- northeasterly winds with similar velocities blew at the rear of cold fronts. In June the moon was waning and, during other periods, sampling was carried out under new or crescent moons. During the campaigns of April, May and the first day $\left(15^{\text {th }}\right)$ of the November campaign in 1996, winds were stronger. In April, the wind speed was were indicative of a cold front incursion (Ayoade 1988). During November, under the Southern Tropical Anticyclone domain, wind velocities reached 21 knots. In April and May, winds due to cold fronts came from the southeast and, in November, winds related to the trade winds came from the northeast. These meteoro- 


\section{TABLE II}

Wave climates and estimated sediment loads transported by longshore currents. Types of wave breaking: C (collapsing or surging); P (plunging) and S (spilling): $\alpha^{\circ}$ Direction and angle of incidence between wave crest and beach alignment. $\mathrm{Qs}\left(\mathrm{m}^{3} / \mathrm{day}\right):$ Estimated volume of sediments transported by longshore currents using Komar's (1976) method $\times 1000$.

\begin{tabular}{|c|c|c|c|c|c|c|}
\hline & $\begin{array}{c}\text { Breaking } \\
\text { type }\end{array}$ & $\alpha^{\circ}$ & Qs (m³/day) & $\begin{array}{c}\text { Breaking } \\
\text { type }\end{array}$ & $\alpha^{\circ}$ & Qs ( $\mathrm{m}^{3} /$ day) \\
\hline $\operatorname{Jan} 96$ & $\mathrm{C}$ & $35^{\circ} \mathrm{S}$ & 50.00 & $\mathrm{P}$ & $15^{\circ} \mathrm{S}$ & 05.96 \\
\hline Feb 96 & $\mathrm{C}$ & $13^{\circ} \mathrm{S}$ & 02.26 & $\mathrm{P}$ & $14^{\circ} \mathrm{S}$ & 02.53 \\
\hline Mar 96 & $\mathrm{C}$ & $07^{\circ} \mathrm{S}$ & 12.87 & $\mathrm{P}$ & $08^{\circ} \mathrm{S}$ & 03.67 \\
\hline Apr 96 & $\mathrm{C}$ & $25^{\circ} \mathrm{N}$ & 86.29 & $\mathrm{P}$ & $18^{\circ} \mathrm{N}$ & 21.19 \\
\hline May 96 & $\mathrm{C}$ & $10^{\circ} \mathrm{N}$ & 13.98 & P-C & $12^{\circ} \mathrm{N}$ & 10.54 \\
\hline Jul 96 & $\mathrm{C}$ & $09^{\circ} \mathrm{S}$ & 12.63 & $\mathrm{~S}-\mathrm{C}$ & $10^{\circ} \mathrm{S}$ & 01.70 \\
\hline Aug 96 & $\mathrm{C}$ & $25^{\circ} \mathrm{N}$ & 43.34 & $\mathrm{P}$ & $13^{\circ} \mathrm{S}$ & 09.59 \\
\hline Oct 96 & $\mathrm{C}$ & $16^{\circ} \mathrm{N}$ & 28.18 & $P$ & $13^{\circ} \mathrm{S}$ & 05.25 \\
\hline Nov 96 & $\mathrm{C}$ & $13^{\circ} \mathrm{S}$ & 81.48 & $\mathrm{P}-\mathrm{C}$ & $22^{\circ} \mathrm{S}$ & 28.39 \\
\hline \multirow[t]{2}{*}{ Jan 97} & $\mathrm{C}$ & $15^{\circ} \mathrm{S}$ & 18.13 & $\mathrm{P}$ & $13^{\circ} \mathrm{S}$ & 18.13 \\
\hline & \multicolumn{3}{|c|}{ P3 } & \multicolumn{3}{|c|}{$\mathrm{P} 4$} \\
\hline Jan 96 & P-S & $15^{\circ} \mathrm{S}$ & 06.79 & P-S & $10^{\circ} \mathrm{N}$ & 04.08 \\
\hline Feb 96 & $\mathrm{P}$ & $10^{\circ} \mathrm{S}$ & 02.14 & $\mathrm{P}$ & $15^{\circ} \mathrm{S}$ & 01.93 \\
\hline Mar 96 & P-S & $07^{\circ} \mathrm{S}$ & 00.93 & $\mathrm{P}$ & $12^{\circ} \mathrm{S}$ & 10.54 \\
\hline Apr 96 & $\mathrm{P}$ & $15^{\circ} \mathrm{N}$ & 17.20 & $\mathrm{P}$ & $10^{\circ} \mathrm{N}$ & 16.00 \\
\hline May 96 & P-S & $08^{\circ} \mathrm{N}$ & 03.29 & $\mathrm{P}$ & $11^{\circ} \mathrm{N}$ & 11.41 \\
\hline Jul 96 & S-P & $08^{\circ} \mathrm{S}$ & 04.99 & S & $13^{\circ} \mathrm{N}$ & 09.59 \\
\hline Aug 96 & P-C & $18^{\circ} \mathrm{N}$ & 17.90 & P-S & $20^{\circ} \mathrm{N}$ & 32.10 \\
\hline Sep 96 & S-P & $16^{\circ} \mathrm{S}$ & 21.68 & $\mathrm{P}-\mathrm{C}$ & $18^{\circ} \mathrm{S}$ & 24.03 \\
\hline Oct 96 & $\mathrm{P}$ & $22^{\circ} \mathrm{S}$ & 09.00 & $\mathrm{P}$ & $20^{\circ} \mathrm{S}$ & 26.28 \\
\hline Nov 96 & $\mathrm{P}-\mathrm{S}$ & $15^{\circ} \mathrm{S}$ & 12.95 & $\mathrm{P}$ & $26^{\circ} \mathrm{S}$ & 20.41 \\
\hline \multirow[t]{2}{*}{ Jan 97} & P-S & $12^{\circ} \mathrm{S}$ & 07.93 & P-S & $10^{\circ} \mathrm{S}$ & 06.44 \\
\hline & \multicolumn{3}{|c|}{ P5 } & \multicolumn{3}{|c|}{ P6 } \\
\hline $\operatorname{Jan} 96$ & $\mathrm{P}$ & $20^{\circ} \mathrm{S}$ & 06.04 & $\mathrm{P}$ & $15^{\circ} \mathrm{N}$ & 06.04 \\
\hline Feb 96 & S & $25^{\circ} \mathrm{S}$ & 09.73 & S & $20^{\circ} \mathrm{S}$ & 11.65 \\
\hline Mar 96 & $\mathrm{P}$ & $20^{\circ} \mathrm{N}$ & 27.14 & $\mathrm{P}$ & $25^{\circ} \mathrm{N}$ & 27.14 \\
\hline Apr 96 & - & - & - & $\mathrm{P}$ & $23^{\circ} \mathrm{N}$ & 38.31 \\
\hline May 96 & $\mathrm{P}$ & $18^{\circ} \mathrm{N}$ & 17.90 & $\mathrm{P}$ & $18^{\circ} \mathrm{N}$ & 17.90 \\
\hline Jul 96 & P-S & $12^{\circ} \mathrm{N}$ & 17.81 & $\mathrm{P}$ & $13^{\circ} \mathrm{S}$ & 13.40 \\
\hline Aug 96 & $\mathrm{P}$ & $16^{\circ} \mathrm{N}$ & 23.19 & S-P & $22^{\circ} \mathrm{N}$ & 12.59 \\
\hline Sep 96 & $\mathrm{P}$ & $06^{\circ} \mathrm{S}$ & 08.49 & $\mathrm{P}-\mathrm{S}$ & $08^{\circ} \mathrm{N}$ & 14.66 \\
\hline Oct 96 & $\mathrm{P}$ & $10^{\circ} \mathrm{N}$ & 13.98 & $\mathrm{P}$ & $10^{\circ} \mathrm{N}$ & 04.71 \\
\hline Nov 96 & $\mathrm{P}$ & $11^{\circ} \mathrm{S}$ & 17.52 & S-P & $14^{\circ} \mathrm{S}$ & 19.19 \\
\hline
\end{tabular}


logical conditions were characterized by waves with a height of 2 to $3 \mathrm{~m}$, and an average period of $5 \mathrm{~s}$, when sampling was done under new moon conditions.

\section{Breaking WaVe Conditions and Tidal LeVEls DURING TOPOGRAPHIC MEASUREMENTS}

The Doce River delta plain beaches exhibit breaking wave heights that are characteristically greater than $1 \mathrm{~m}$, independently of tidal level (Fig. 6). The Barra do Riacho (P1) beach showed collapsing breaking waves (Table II), whose highest value took place during the April campaign when the waves conditions were dominated by a cold front and low tidal level.

In Comboios, Regência and Povoação (P2 to P6), the wave heights ranged from 0.7 to $2 \mathrm{~m}$. On the foreshore of this stretch of coast, waves in the breaking zone become more slender and plunging. Alternatively, and perhaps additionally, spilling breaking waves develop in the surf zone, due to the stock of sediments. The biggest wave heights occurred in April, August and November of 1996, and were always associated with a cold front passing throut the area (Table II).

At the beaches between Barra do Riacho and Povoação, meteorological conditions directly influence longshore currents directions and transportation capacities (Table II). Higher angles of waves with higher breaking waves $\left(\mathrm{H}_{\mathrm{b}}\right)$, promote the greater transportation capacity of this stretch of coast.

\section{Topographic Changes of Beach Profiles}

The southern portion of the Doce River delta plain belongs to an Indian Reservation, and to a TAMAR (Tartarugas Marinhas) Biological Reservation and so, is relatively well preserved.

The southernmost beach profiles (P1 and P2) show higher and more inclined beach ridges when compared with the northern ones (P3 and P4), (Figs. 7 and 8).

Except for the May, July and August 1996 campaigns, when a small recession was observed, Barra do Riacho (P1) beach remained stable throughout the year.

The Comboios ( $\mathrm{P} 2$ ) beach profile was very changeable. A $15 \mathrm{~m}$ recession in the beach-ridge front was observed over the study interval. In February 1996, the development of two berms and the foreshore deposition of sands were verified. In April 1996, the erosion of a vegetated beach-ridge began, which continued through May 1996 and the following campaigns until January 1997, when these surveys stopped.

The 80 to $105 \mathrm{~m}$ long beach profile (P3) on the same beach is comprised of foredunes constantly disturbed by water drainage channel construction by the TAMAR Project, (Fig. 8). During the first three campaigns of 1996, the backshore showed a tendency towards sedimentation, with longitudinal trough and bank development in January, and a sandy terrace in February and March. However, a recession was observed in April, followed by a bigger advance in May 1996. During the July and August campaigns, the tendency towards recession returned. From September 1996, this beach's profile began to advance once again and, at the end of the management period, was characterized by small morphological changes.

The Regência beach profile (P4) was in retrogradation during the first campaign, with a moderate beachface slope and foreshore terrace, (Fig. 8). During the following campaigns a beach profile progradation occurred, which was interrupted during the campaigns of August and September 1996. The most intensive sedimentation occurred in November 1996, while a small sand withdrawal occurred in January 1997. Finally, comparing the beach profiles of January 1996 and 1997, a small recession was observed.

The Povoação beach profile (P5) presents a vegetated beach ridge with foredunes preserved at the rear. In the January 1996, campaign it showed a foreshore sandy terrace. In the February and May campaigns, this profile prograded, interrupted by a short recession episode in March (Fig. 9). In July 1996 an intense erosion occurred, which destroyed about $20 \mathrm{~m}$ of the stable berm. A tendency towards recession persisted during other campaigns and increased in September 1996. A comparison of the January and November 1996 profiles showed that the beach profile did not completely recover. The topographic behavior of the profile P6 during the first four campaigns was different from P5, but similar to others (Fig. 9). This profile showed a retreat in February, April and May, and an advance in March, when compared to the situation at the beginning of the study period, in January 1996. A retreat began from July, and increased in September 1996 due to a cold 

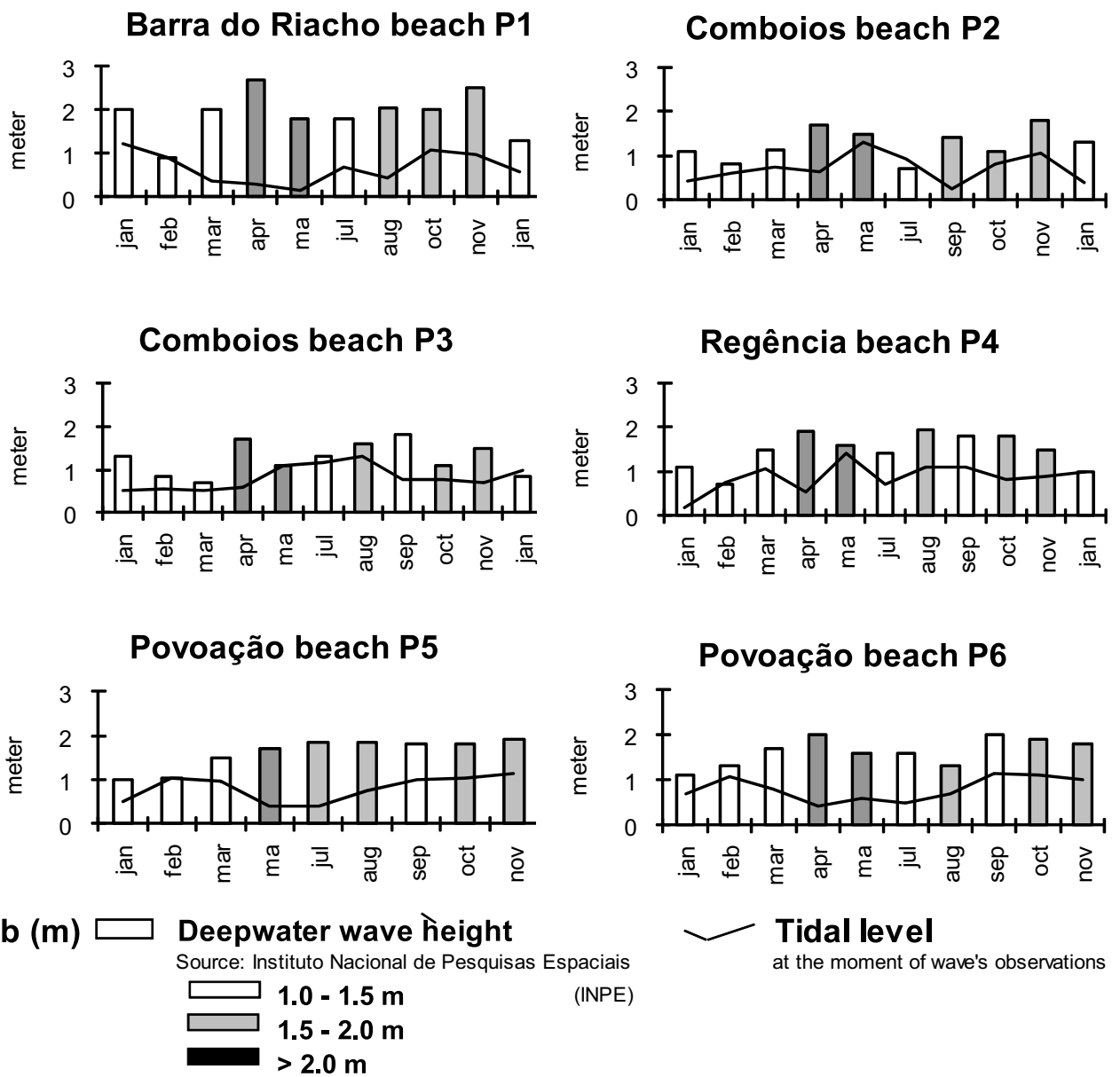

Fig. 6 - The association between wave height in the open sea and the tide level influence in the breaking waves $(\mathrm{Hb})$ on the beaches surrounding the Doce River. The breaking wave-height depends on the deepwave conditions, due to low dissipation on the nearshore and inner continental shelf.

front. By November 1996 a complete recovery had not occurred. This beach profile erosion caused the destruction of some dwellings in the village of Povoação.

The beach profiles changed according to local meteorological conditions. During the influence of trade winds, with longshore currents from north to south, fluvial sediments are predominantly transported southward, with the updrift side of the river mouth being eroded simultaneously. The southward transportation of sediments is suggested by the coarsening and increasing roundedness of beach sands, which were recorded in the entire beach arc between the Doce and Riacho Rivers. Near the Riacho River, this transportation of sediments was suggested by reversed beach profiles. From October 1996 to January 1997, under the influence of the trade winds, Comboios beach exhibited ero- sion to the north, and Barra do Riacho exhibited progradation to the south.

The inversion of the longshore drift current, acting from south to north, was observed between May and August 1996, when cold front incursions were more frequent. The Barra do Riacho (P1) profile retreated, while the Comboios (P2 and P3) beach profiles advanced.

The cold front incursions to the Espírito Santo State coast intensified rainfall. As a result, the Doce River discharge and its efficiency as hydraulic jetty increases, which causes the transportation of sediments coming from the south to be blocked. Therefore, from May 1996, under cold fronts with intense rainfall and longshore currents acting from south to north, the Povoação village profiles at the downdrift side of the Doce River mouth receded. 

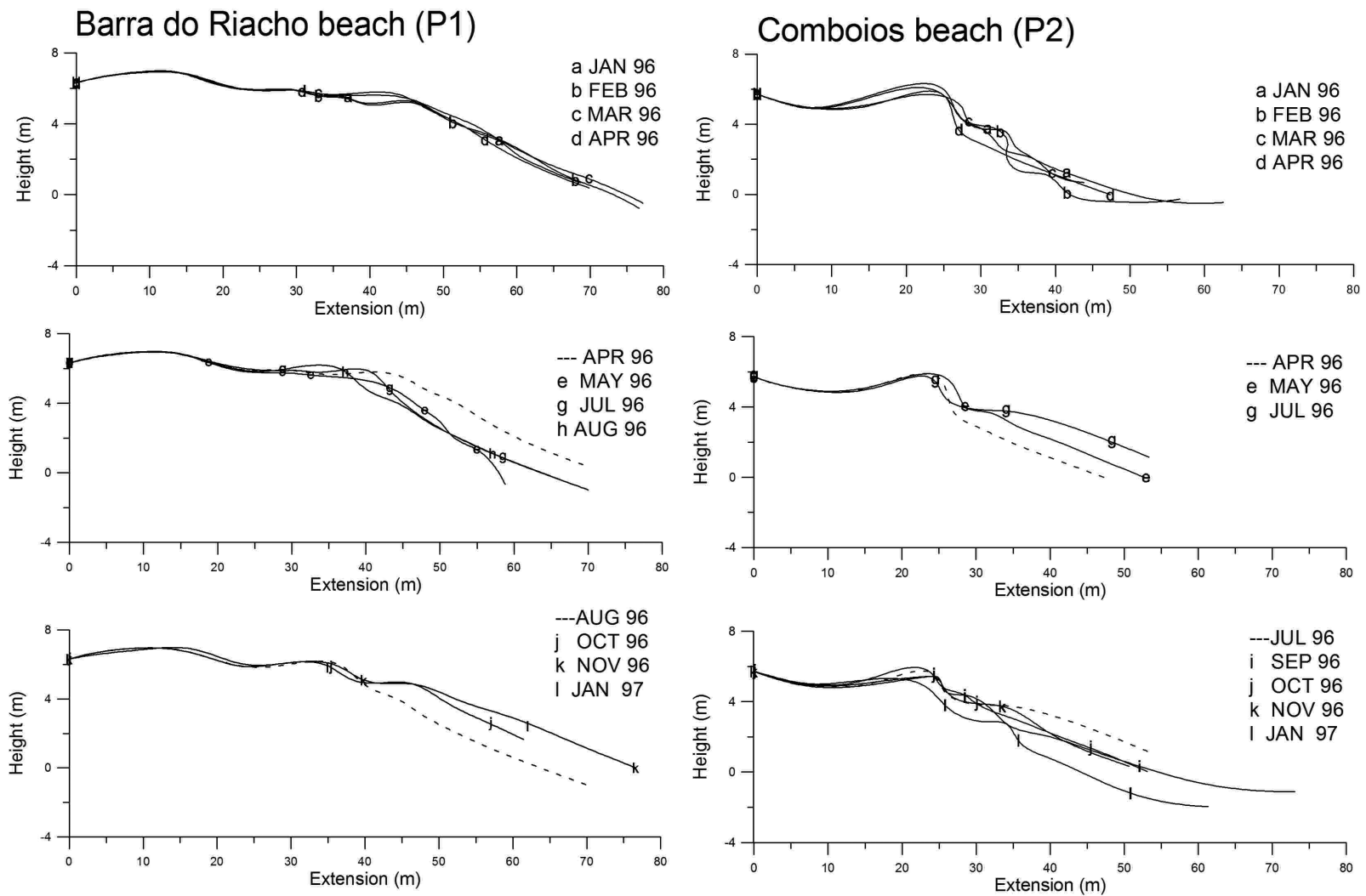

Fig. 7 - Variation in morphology of the Barra do Riacho and Comboios beaches profiles between January and January 1997.

\section{Sedimentary Processes and Present Beach} TYPOLOGY

The inner continental facies of shelf sediments in the surroundings of the Doce River mouth and the distributions of grain size on present-day beaches of the studied area suggest that sediments presently supplied by this river mostly influence the area surrounding its mouth. Beach sand is supplied by longshore drift and also by the Riacho River to the south, whose loads create stable or prograding tendencies in adjacent beaches.

The rainfall that followed the passage of cold fronts gave rise to an increase in Doce River discharge, when the sands transported by longshore currents from the south were blocked by river flow. During this time, Povoação beach, situated northward of the Doce River mouth, was in poor condition and underwent erosion. By contrast, the Regência (P4) beach profile, located southward of the mouth, exhibited sedimentation.

Inversions in longshore currents and the hydraulic jetty effect of the Doce River mouth cause deposition of fluvial and marine sediments transported by long- shore currents, south or north of the mouth. They have been retained in the foreshore as wave-built terraces and banks, which contribute to the variability of beach types to the coarseness or fineness of sands that is assigned to distinct beach processes. Using the approach to beach classification presented in Wright et al. (1979), the beaches can be characterized as intermediately morphodynamic. They present seasonal alternation of the four stages exhibiting important topographic changes as a function of variations in fluvial discharges and meteorological conditions.

The Barra do Riacho beach, which is not at present nourished by the Doce River, is characterized by a steep slope foreshore, which promotes the entry of high spilling breaking waves that favor the intense transfer of sands between inner continental shelves and adjacent beaches. The emergent beach profile retreated a little during cold front incursions, with a consequent intensification of wave energy.

The breaking wave type, the declivity and the coarse-grained, well-sorted sands found during the 

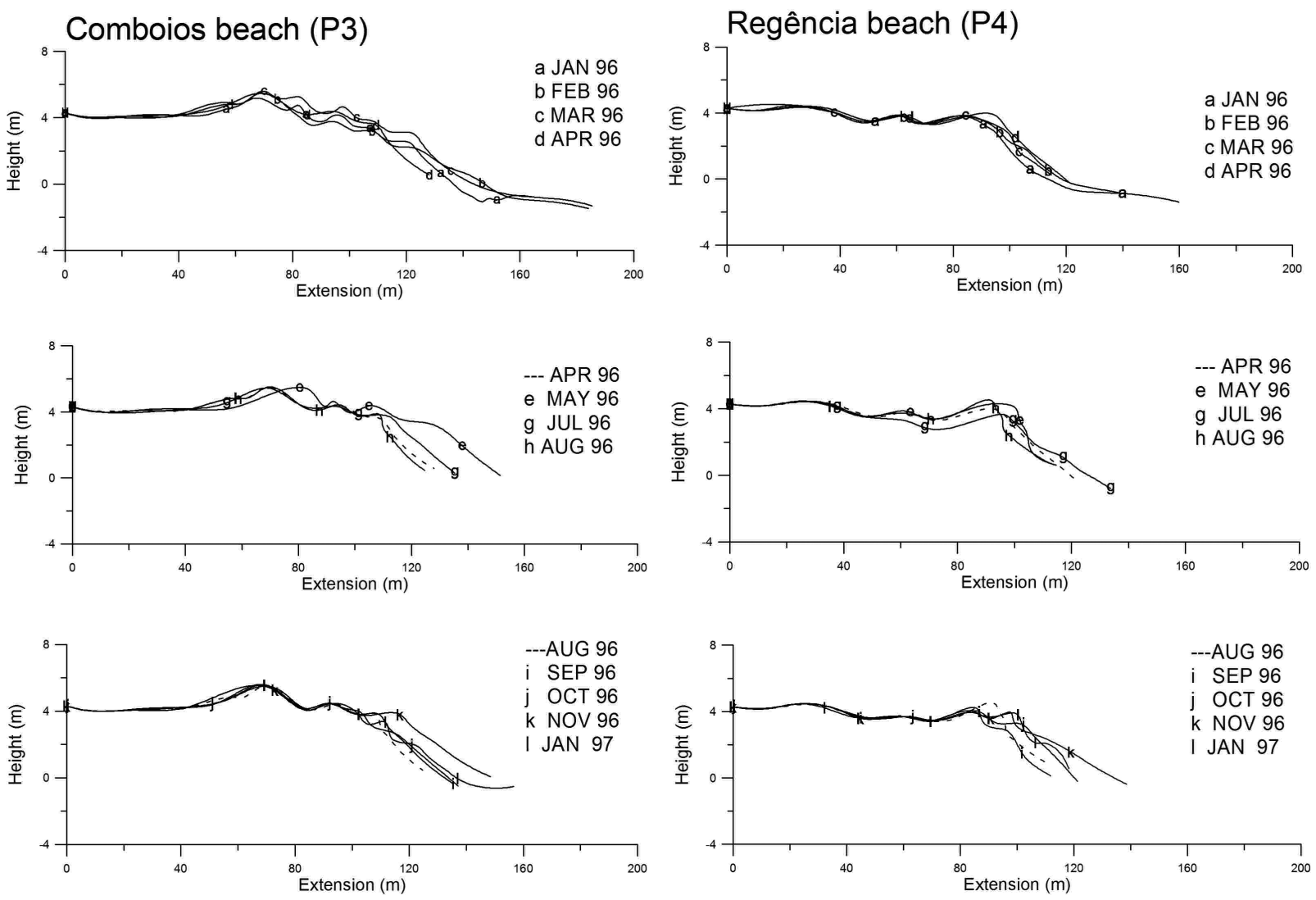

Fig. 8 - Morphological variation of the Regência beach profiles between January 1996 and January 1997.

management interval allowed the recognition of a reflective stage beach, in this case.

\section{CONCLUSION}

The present beach morphodynamics, directly influenced by the Doce River mouth, represents a continuation of hydrodynamic processes that started about $2.5 \mathrm{ky} \mathrm{BP}$, according to Suguio and Martin (1981) and Martin and Suguio (1992). Alternating constructive and destructive events next to Doce River mouth have been identified from that time, as suggested by Dominguez et al. (1983) during the evolution of the beach-ridge plain.

The Barra do Riacho and Povoação beaches, situated adjacent to the Doce River mouth, exhibited prograding tendencies due to the continuous sediments supplied by the river. However, the Povoação beach presented erosional events associated with the incursion of cold fronts, and a subsequent increase in river discharge that caused a downdrift deficit of sediments, with beach profile disequilibrium.
The beach-ridge plain at the rear of the present Doce River mouth beaches is still well preserved due to relatively sparse human occupation of the area. The sands of these beach-ridge plains, as well as those of local dunefields and other present-day beaches, could be easily reworked in response to possible future rises in sea level or sazonal floods according to the model for readjusting beach profiles proposed by Bruun (1962).

\section{ACKNOWLEDGMENTS}

The authors are very grateful to FAPESP (Fundação de Amparo à Pesquisa do Estado de São Paulo) for the necessary financial support for field work, and to the Projeto TAMAR-IBAMA (Projeto Tartarugas Marinhas - Instituto Brasileiro de Meio Ambiente) for facilitating the sampling of the inner continental shelf.

\section{RESUMO}

A sedimentação costeira adjacente à desembocadura do Rio Doce, Espírito Santo, Brasil destaca o efeito de jato hidráulico desempenhado pela descarga fluvial. Por ocasião da enchente, 

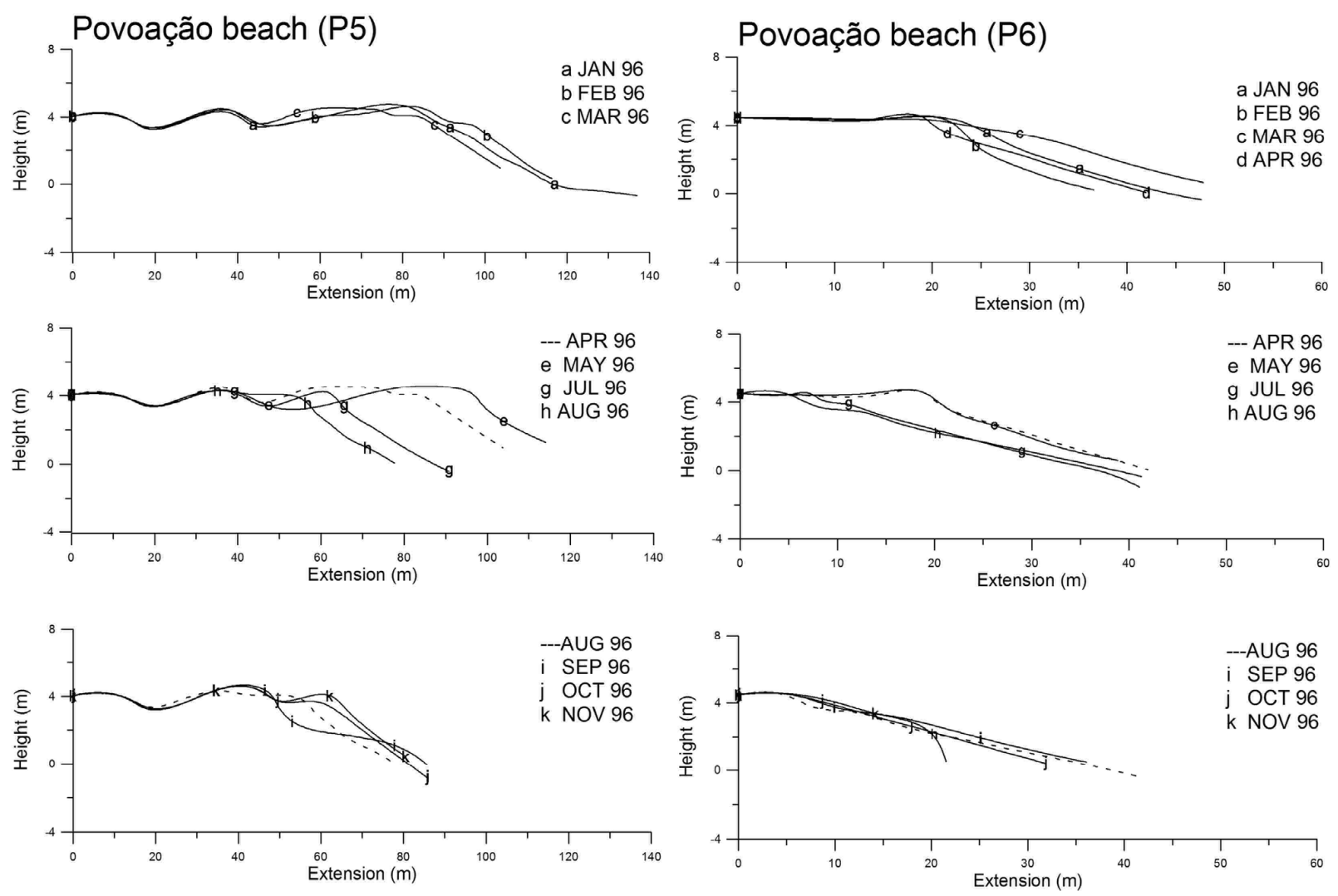

Fig. 9 - Morphological variation of the Povoação beach profiles between January and November 1996.

os sedimentos marinhos transportados pela corrente longitudinal são represados a barlamar da desembocadura, causando progradação nas praias adjacentes e erosão nas praias situadas a sotamar da desembocadura fluvial. Com a inversão do rumo da deriva litorânea, os processos erosivos e construtivos se invertem. Estudos sedimentológicos realizados nos sedimentos do rio, das praias e da plataforma continental interna adjacente à desembocadura, indicam que a contribuição da carga do rio Doce é atualmente restrita às áreas imediatamente vizinhas. Contudo, a tipologia das praias e os processos de sedimentação da planície costeira são diretamente afetados pela descarga do rio Doce, sendo a continuação dos processos de sedimentação identificada na evolução geológica da área.

Palavras-chave: processos costeiros, morfodinâmica praial, evolução Quaternária, rio Doce, Brasil.

\section{REFERENCES}

Asmus He, Gomes JB And Pereira ACB. 1971. Integração geológica regional da bacia do Espírito Santo. In: Congresso Brasileiro de Geologia (SBG), XXV, São Paulo, SP, Brasil, Anais 3: 235-254.
Aubrey DG. 1983. Beach changes on coasts with different wave climates. In: MCLACHLAN A AND ERASMUS T (Eds), Sandy beaches as ecosystems. The Hague: Dr. Junk Publishers, p. 63-85.

AYOADE JO. 1988. Introdução à Climatologia para os Trópicos: Bertrand - Brasil, Rio de Janeiro, RJ, Brasil, 323 p.

BRUUN P. 1962. Sea level rise as a cause of shore erosion. Journal of the Waterways and Harbors Division. Am Soc Civil Engineers 88: 117-130.

Coutinho JMV. 1974. Os minerais pesados de areia na foz do rio Doce. In: Congresso BRASILEIRO DE GEOLOGIA (SBG), XXVIII, Porto Alegre, RS, Brasil, Anais 5: $61-77$.

DHN - Diretoria de Hidrografia E NAVEGaÇão. 1996. Tábua de Marés. Terminal de Barra do Riacho, p. 36.

DHN - Diretoria de Hidrografia E NAVEGAÇão. 1997. Tábua de Marés. Terminal de Barra do Riacho p. 36.

Dominguez JML, Bittencourt ACSP And MARTin L. 1983. O papel da deriva litorânea de sedimentos arenosos na construção das planícies costeiras associadas a desem- 
bocaduras dos rios São Franscisco (SE/AL), Jequitinhonha (BA), Doce (ES) e Paraíba do Sul (RJ). Rev Bras Geocienc 13: 93-105.

FOLK R AND WARD W. 1957. Brazos river bar. A study in the significance of grain size parameters. J Sediment Petrol 27: 3-26.

FRANÇA AMC. 1979. Geomorfologia da margem continental leste brasileira e da bacia oceânica adjacente. In: Geomorfologia da margem continental leste brasileira e das áreas oceânicas adjacentes. Série Projeto Remac 7: 89127.

INPE - Instituto NACIONAL DE PESQUisas EsPaCiAis. 1998. Climanálise (online). Available: <http:/cptec > (captured on September 30).

Komar PD. 1976. Beach Processes and Sedimentation, Englewood Cliffs, N.Y. Prentice-Hall, 429 p.

LARSONNEUR C. 1977. La cartographie des dépots meubles sur le plateau continetal français: methode mise au point et utilisée en Manche. J Rech. Oceanographiques 2: 34-39.

MARTIN L AND Suguio K. 1992. Variation of coastal dymanics during the last 7,000 years recorded in beachrigde plains associated with river mouths: Example from the central Brazilian coast. Palaeogeogr, Palaeoclimatol, Palaeoecol, 99: 119-140.
Martin L, Suguio K, Flexor JM And Archanjo JD. 1996. Coastal Quaternary formations of the southern part of the State of Espírito Santo (Brazil). An Acad Bras Cienc 68: 389-404.

Melo E And Gonzalez J DE A. 1995. Coastal Erosion at Camburi Beach (Vitoria, Brazil) and its Possible Relation to Port Works. In: International Conference on Coastal and Port Engineering in Developing Countries (COPEDEC), IV Rio de Janeiro, RJ, Brazil, Proceedings, p. $397-411$.

Pettijonh FJ. 1957. Sedimentary rocks: New York, Harper $\&$ Bros, $718 \mathrm{p}$

Suguio K AND Martin L. 1981. Significance of Quaternary sea-level fluctuations for delta construction along the Brazilian Coast. Geo-Mar Lett 1: 181-185.

Wentworth CK. 1922. A scale of grade and class terms for clastic sediments. J Geol 30: 377-392.

Wright LD AND SHORT AD. 1984. Morphodynamics variability of surf zones and beaches: a synthesis. Mar Geol 56: 93-118.

Wright LD, Chappell J, ThOM MBG, BRAdShaW MP AND COWEll P. 1979. Morphodynamics of reflective and dissipative beach and inshore systems: Southeastern Australia. Mar Geol 32: 105-140. 